\title{
ユニオンメルト自動熔接罐胴の残留應力こ 燒鈍に依ろ應力緩和度の測定*
}

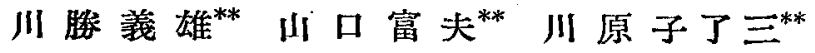
Measurement of Residual Stresses on the Unionmelt Arc Welded Pressure Vessel and the Effect of Stress Relieving Heat Treatment*

By K. Kawakatsu, ${ }^{* *}$ T. Yamaguchi, ${ }^{* *}$ and R. Kawarago**

\begin{abstract}
The residual stresses of the Unionmelt arc welded pressure vessel were measured on the longitudinal and circumferential weld lines. For the longitudinal seams, the same measurement was made after the 2.5 hours annealing at the temperature of $625 \pm 25^{\circ} \mathrm{C}$, and tested the effect of stress relief by annealing.

For the thick plate such as this test drum, the residual stresses are triaxial and have certain distribution in the direction of thickness. Therefore, the successive slicing method, developed by $D$. Rosenthal and J. T. Norton, was used for this investigation.

As the result of measurement, the residual stresses of maximum about $50 \mathrm{~kg} / \mathrm{mm}^{2}$ was found in the both longitudinal and transverse directions of the interior of the longitudinal weld lines. These stresses were diminished to abut $10 \mathrm{~kg} / \mathrm{mm}^{2}$ by annealing.

In the interior, the residual stresses on the circumferential weld lines are about $20 \mathrm{~kg} / \mathrm{mm}^{2}$ in tension. This value is less than those of the longitudinal weld line; on the both surfaces, they are in compression.

The residual stresses in the direction of thickness are highest in the middle part but they are very small and less than $1 \mathrm{~kg} / \mathrm{mm}^{2}$.
\end{abstract}

\section{1 緒 言}

橴接残留応力の測定は彷来から各方面で行われその測定 例毛少なくないがこてれらの多くは溥板母材の場合でボイ ラードラムの如き憬板母材について測定された例は少ない ようである. 本測定では板厚 $55 \mathrm{~mm}$ 内径 $1200 \mathrm{~mm}$ の試 作罐䏤の継手をユニオンメルトで自動熔接した場合の残留

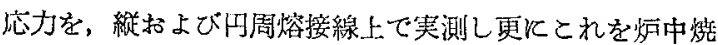
鈍した場合どの程度の応力緩和が行われるものであるかを 明らかとした．母材の板厚が愿くなると残留忘力む三軸応 力となりその分布も板厚方向に対し一㥞でない，かようの 場合の内部応力测定法としては既に D. Rosenthol 扔よび J. T. Norton が Welding Journal 誌 (1954年 5 月) 飞発 表している.そこで筆者などもこの方法を用いて実物大の 䍊婀継手の残留応力を測定した.

\section{D. Rosenthal および J. T. Norton の残留応力測定理論 ${ }^{12}$}

Fig. 1 の如き二枚の衝合熔接した熔接線上の残留応力 を测定する場合《ついて考える. 残留応力分布は熔接線の 両側に対称的でありかつその主応力は熔接線の方向和よび これと直角方向《存在するものとする．先ず応力測定部位

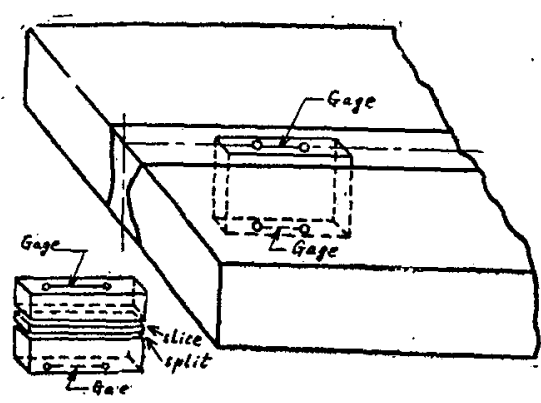

Fig. 1 Removal of a block with gages attached

の両面胝 抗線歪計多 一ジを熔接 線方向括よ びこれと值 角方向飞㙋 り図の如 $<$, Longi. あるいは Trans.方向 の Block K

切り離す，Block の巾が充分狭い時は長さ方向の応力はを の一部が解除されるに比して币方向の忘力汪とんど全部 が解除せられるむのと洘えてよい。しかして Blockの長さ を板厚の 2 倍以上飞すれば Block の中央部代括いて解除さ れる舆さ方向の応力は值線的の分布を持ちまたとの大きさ は両端炕招いて解除される心力の平均值に等しいことが理 諭括よび实験から証明せられている. 長さが 2 倍以下の場

* 原稿受付 昭和29年11月20日（昭和29年度跧接学全 秋季学術講演会に招いて登表)

**正员，新三菱重工神户造船所 Member, Kobe Shipyard, Shinmitsubishi Heavy Ind. Co. 
合に江平均値以上の解除力，起る.

（a）さて Block に切り離した時飞解除される緃执よび 横方向の Stress, Strain をとれそれ $S_{l}^{\prime}, S_{t}{ }^{\prime}, e_{l}^{\prime}, e_{t}^{\prime}$ とし， その後の削除によるものを $S_{l}{ }^{\prime \prime}, S_{t}{ }^{\prime \prime} ; e_{l}{ }^{\prime \prime}, e_{t}{ }^{\prime \prime}$ とすれば，辰 さが厚さの 2 倍以上の㭙は次の関係が成立する.

$$
\begin{aligned}
& S_{\imath}^{\prime}=\frac{E}{1-\nu^{2}}\left(e_{l}+\nu e_{t}{ }^{\prime}\right)+\frac{\nu E}{1-\nu^{2}}\left(e_{t}^{\prime \prime}+\nu e_{l}^{\prime \prime}\right) \\
& S_{t}^{\prime}=\frac{E}{1-\nu^{2}}\left(e_{t}^{\prime}+\nu e_{l}^{\prime}\right)+\frac{\nu E}{1-\nu^{2}}\left(e_{l}^{\prime \prime}+\nu e_{t}^{\prime \prime}\right)
\end{aligned}
$$

長さが厚さの 2 倍以下の場合には（1）式で表わされる 心力ょり更に余分の闷力が解除也られる.この余分の解除 応力の $S^{N}$ 飞対する割合を $\beta$ とすれば，

$$
\left.\begin{array}{l}
S_{l}^{\prime}=\frac{E}{1-\nu^{2}}\left(e_{l}^{\prime}+\nu e_{t}^{\prime}\right)+\frac{E}{1-\nu^{2}}\left(\nu e_{t}^{\prime \prime}+\frac{\nu^{2}-\beta}{1-\beta} e_{l}^{\prime \prime}\right) \\
S_{t}^{\prime}=\frac{E}{1-\nu^{2}}\left(e_{t}^{\prime}+\nu e_{l}^{\prime}\right)+\frac{E}{1-\nu^{2}}\left(\nu e_{l}^{\prime \prime}+\frac{\nu^{2}-\beta}{1-\beta} e_{t}^{\prime \prime}\right)
\end{array}\right\}
$$

辰さを厚さの1.5倍とすれば実駼的に $\beta=0.15$ となり, 更に $E=2.1 \times 10^{4} \mathrm{~kg} / \mathrm{mm}^{2}, \nu=0.3$ を入机（2）式を計 算すると次の如くなる.

$$
\left.\begin{array}{l}
S_{l}{ }^{\prime}=2.31 \times 10^{4}\left(e_{l}{ }^{\prime}+0.3 e_{t}{ }^{\prime}\right)+0.692 \times 10^{4}\left(e_{t}{ }^{\prime \prime}-0.235 e_{l}{ }^{\prime \prime}\right) \\
S_{t}{ }^{\prime}=2.31 \times 10^{4}\left(e_{t}{ }^{\prime}+0.3 e_{l}^{\prime}\right)+0.692 \times 10^{4}\left(e_{l}{ }^{\prime \prime}-0.235 e_{t}{ }^{\prime \prime}\right)
\end{array}\right\}
$$

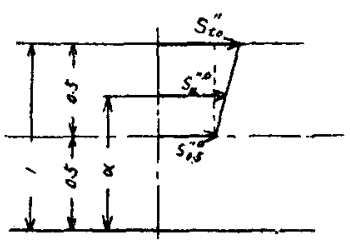

Fig. 2
以上は板の両表面に招い て解除された応力と歪と の関係であるが，板の内． 部ではこれらの值が板厚 方向に直線的比分布する ものと見做して直ちに求 まる。

（b）次にこの Block を板厚中心でニつに分㫼して場合 次上下雨面で解除される応力を $S_{t}^{n}, S^{\prime \prime}{ }_{2}^{0}$ とすれ切切断面

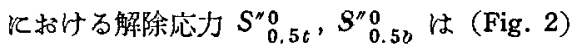

$$
\left.\begin{array}{l}
S_{0.5 t}^{\prime \prime}=-\frac{3}{2} S_{t}^{\prime \prime}+\frac{1}{2} S_{b}^{n}=E\left(-\frac{3}{2} e_{t}^{\prime \prime}+\frac{1}{2} e_{t}^{n}{ }_{t}\right) \\
S_{0.5 b}^{\prime \prime 0}=-\frac{3}{2} S_{b}^{\prime 0}+\frac{1}{2} S_{t}^{\prime \prime}=E\left(-\frac{3}{2} e_{b}^{\prime \prime}+\frac{1}{2} e_{t}^{n 0}\right)
\end{array}\right\}
$$

往って任意の層に和ける值は位置を底面より $\alpha$ とすれ ば，応力分布の直線性より上下の各半 Block飞対しては それをれ

$$
\begin{aligned}
& S^{\prime \prime}{ }_{\alpha, t}^{0}=(5 \alpha-4) S^{\prime}{ }_{t}^{0}+(1-\alpha) S_{b}^{\prime \prime 0} \\
& =E\left[(5 \alpha-4) e^{\prime \prime}{ }_{t}+(1-\alpha) e_{b}^{\prime \prime 0}\right] \\
& S_{a, b}^{\prime \prime}=(5 \alpha-4) S^{\prime \prime}{ }_{b}+(1-\alpha) S^{\prime \prime}{ }_{c} \\
& =E\left[(5 \alpha-4) e_{b}^{\prime \prime 0}+(1-\alpha) e_{t}^{\prime \prime 0}\right]
\end{aligned}
$$

（c）Blockを二つに分割した時に未だ內部に存在してい る残留灾力を $S^{\prime \prime \prime}$ とすれば，分割面より外表面に向って
逐次切削した場合の任意の位置に招ける芯力は次式の如く 表わされる。

$$
\begin{aligned}
S_{\alpha}^{\prime \prime \prime}= & E\left[\frac{1}{2} \frac{d e_{t}^{\prime \prime}}{d \alpha}(1-\alpha)-2\left(e_{t}^{\prime \prime}-e_{t}^{\prime \prime 0}\right)+3(1-\alpha)\right. \\
& \left.\times \int_{0.5}^{\alpha} \frac{e_{t}^{\prime \prime}-e^{\prime \prime 0}}{(1-\mu)^{2}} d \mu\right] \\
S_{\alpha}^{\prime \prime}= & S_{\alpha}^{\prime \prime 0}+S_{\alpha^{\prime \prime \prime}} \text { なる故K } \\
S_{\alpha}^{\prime \prime}= & E\left[\frac{1}{2} \frac{d e_{t}^{\prime \prime}}{d \alpha}(1-\alpha)-2\left(e_{t}^{\prime \prime}-e_{t}^{\prime \prime}{ }_{t}^{0}\right)+3(1-\alpha)\right. \\
\times & \left.\int_{0.5}^{\alpha} \frac{e_{t}^{\prime \prime}-e_{t}^{\prime \prime}}{\left(1-\mu^{2}\right)} d \mu+(5 \alpha-4) e_{t}^{\prime \prime}{ }_{t}+(1-\alpha) e_{b}^{\prime \prime 0}\right]
\end{aligned}
$$

上式は上半分の Block に対するあのであるが下半分に

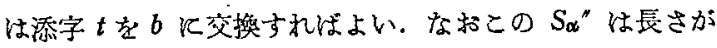
厚さの 2 倍以上の場合であり，てれより短いときは（7） 式で求めた值を $\frac{1}{1-\beta}$ 倍すればよい。

な括 $\alpha=0.5$ すなわち最初に Block を二つに分割した 面伙対しては上下両火 Block 関する二つの式から計算さ れるが，これは当然一致すべきすのである.

$$
\left.\begin{array}{l}
S_{0.5}^{\prime \prime}=E\left(\frac{1}{4} \frac{d e_{t}{ }^{\prime \prime}}{d \alpha}-\frac{3}{2} e^{\prime \prime}{ }_{t}+\frac{1}{2} e^{\prime \prime 0}\right) \\
S_{0.5}^{\prime \prime}=E\left(\frac{1}{4} \frac{d e_{b}{ }^{\prime \prime}}{d \alpha}-\frac{3}{2} e_{b}^{\prime \prime 0}+\frac{1}{2} e^{\prime \prime 0}{ }_{t}\right) .
\end{array}\right\}
$$

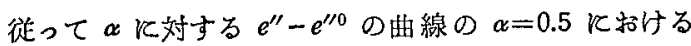
傾斜，すなかち（8）式の为 1 項を調整するのK用いられ ๖.

また Block の最外層の雪は解除歪の分布曲線より extrapolation 法によって求めるかあるいはX線回析法に よって直接測定する.

(d) 厚さ方向の応力は坐標軸を熔接線の方向和よびこれ 之㨁解方向飞 $X, Y$ 䭯, 厚さ方向飞 $Z$ 軸をとって弾性理 諭の平衡条件より次の如く求まる.

$$
\begin{gathered}
\frac{\partial^{2} S_{Z}}{\partial Z^{2}}=\frac{2}{\left(\Delta y_{1}\right)^{2}}\left(S_{y_{1}}-S_{y_{0}}\right)+\frac{2}{\Delta y_{2} \Delta x_{2}} T_{z z 2 y_{2}} \\
T=G\left(e_{w}-e_{v}\right)
\end{gathered}
$$

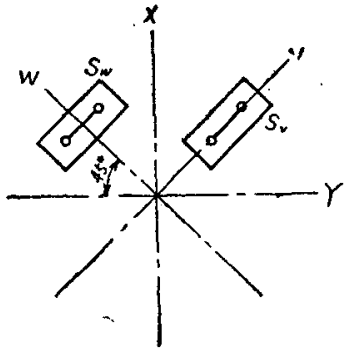

Fig. 3
（9）式を2回積分し表 面炋颃い $S_{Z}=0$ とす れば厚さ方向の忘力分布 が求季る. $T_{x y}$ の板厚方 向分布墩験片を Bolck 《切り離した時の上下面 の测定値が直線的に分有 していると見做してよ w.

\section{3 供 試 罐 同}

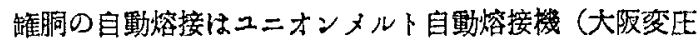


器製）とより鹳胴の縦継手招よび鏡板の円周継手て対して

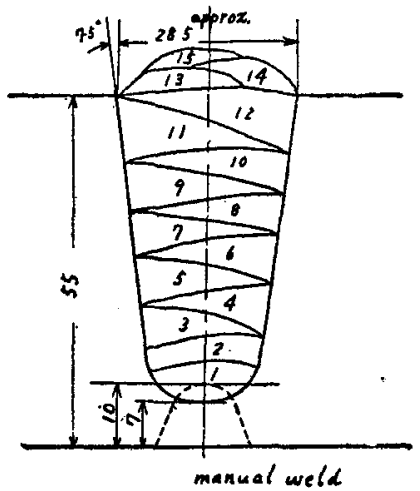

Fig. 4 Edge preparation
行った. 試作し た罐胴の形状は 板厚 $55 \mathrm{~mm}$ 内 径 $1200 \mathrm{~mm}$ 解 粙長 $3100 \mathrm{~mm}$ の ものである.使 用村的 JIS 䍊用 压延鋼板为 3 種 ZSB 46B 材でそ の化学成分就よ び機械的諸性質 注 Table 1 の如 くである. (但し 測定値怯 A, B

二枚の素材の ingot 頂部招よび底部につき試験した値の籍 囲を示す)

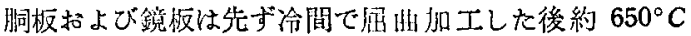
で态力除去焼鈍を行い，その周縁仗 Fig. 4 の如き開先を

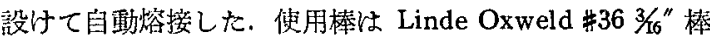

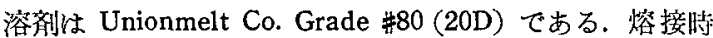
の熔接条件はTable 2 亿示す如くで予熱温度は $150 〜 200^{\circ} \mathrm{C}$ とした.

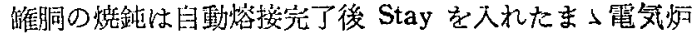
て $625 \pm 25^{\circ} \mathrm{C}$ の温度て2.5時間保持した後これを $300^{\circ} \mathrm{C}$ 迄 炉冷した。

\section{4 測 定 要 領}

矱胴の緹継手あるいは円周継手の愹接残留芯力を測定す る場合には先ず它の測定部位について吟味する必要があ る. 一般に平板の衡合熔接部に生ず る残留応力分布は Longitudinal Stress が熔接線の中央で最大となり 両端では答となる。また Transverse Stress は両端部で王縮方向汇最大と なり中头部で僅かに引張忘力とな

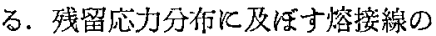
影響については E. Paul De Garmo, J. L. Meriam \& F. Jonassen $の$ 研

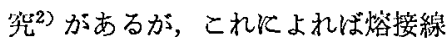
が $20^{\prime \prime}$ より少い恃は Longi. Stressは 中央が毒高で車端が零の分布状態を 示すが，20"より長くなると両端か ら10” はなれは中央部の籁囲ではほ

Table 2 Welding Condition

\begin{tabular}{|c|c|c|c|c|c|c|}
\hline \multirow{2}{*}{$\begin{array}{l}\text { No. of } \\
\text { layers }\end{array}$} & \multicolumn{3}{|c|}{$\mathrm{L}_{1} \quad$ Seam } & \multicolumn{3}{|c|}{$\mathrm{L}_{2}$ Seam } \\
\hline & $\begin{array}{c}\text { Current } \\
\text { A }\end{array}$ & Volt V & $\begin{array}{c}\text { Speed } \\
\mathrm{cm} / \mathrm{min}\end{array}$ & $\begin{array}{c}\text { Current } \\
\mathrm{A}\end{array}$ & Volt V & $\begin{array}{c}\text { Speed } \\
\mathrm{cm} / \mathrm{min}\end{array}$ \\
\hline 1 & 390 & 28 & 35 & 360 & 29 & 35 \\
\hline 2 & 480 & $"$ & $\Rightarrow$ & 450 & " & $"$ \\
\hline 3 & 540 & $"$ & 30 & 510 & $"$ & $"$ \\
\hline 4 & 600 & $\Rightarrow$ & 28 & 600 & $"$ & 30 \\
\hline 5 & 700 & $"$ & $"$ & 660 & $"$ & $"$ \\
\hline 6 & 700 & $"$ & $"$ & 750 & 30 & " \\
\hline 7 & 720 & $\Rightarrow$ & $"$ & $"$ & $\Rightarrow$ & $"$ \\
\hline 8 & 720 & $"$ & 27 & " & $"$ & $"$ \\
\hline 9 & 750 & " & 26 & $"$ & $\Rightarrow$ & $"$ \\
\hline 10 & 750 & $"$ & $"$ & 720 & 28 & 27 \\
\hline 11 & 720 & $"$ & $"$ & " & $"$ & $"$ \\
\hline 12 & 750 & $\Rightarrow$ & 20 & $"$ & $"$ & 20 \\
\hline 13 & 750 & $28 \sim 30$ & 40 & 750 & $"$ & 40 \\
\hline 14 & 750 & $"$ & $"$ & $"$ & " & $"$ \\
\hline 15 & 720 & $28-36$ & 30 & 720 & 32 & 30 \\
\hline
\end{tabular}

とんど応力値は一定となる傾向を示している，またその 最高応力值壮 10 ”迄愹接長の長さと共飞急激に增加す る.これらの点より見て供試罐胴の忍力測定部位は胴体 部では端面より $250 \mathrm{~mm}$ 程度はなれた位置を選ぶことに した. 本測定では端部約 $300 \mathrm{~mm}$ の籁困について応力測 定を行うことよて，胴体の一方の端部走熔接㨁後他他方 の端部を烧鈍後の測定部位に供した，試験片切離し後の 胴体は端面よりガス切断括よび機械切削して軸長 2400 $\mathrm{mm}$ の罐䐀し鏡板の熔接を行った。洞体の縦継手は軸に 刘して坟称位琴飞 $\mathrm{L}_{1} \mathrm{~L}_{2}$ の継手を有するので残留灾力の 測定はこの禹熔接線部 (AC) 括よびこれ之直角斿向の非 熔接部位 (BD) Kついて行うことよした，熔接線上飞怙 ける歪計ダージの貼付位置は Fig. 5 の如くで BD の部 位化对しては平圾の忍力分布のみを求めることつして No. 1, No. 2, No. 6，のゲージのみを貼りつけ他訬略 した．使用した歪計ダージはＫ社慗の K-1（標点距離 $20 \mathrm{~mm}$ 抵抗值 $120 \Omega$ ) である. 
Block の切り出しは個々のグージ 缽比行ってもよいが，これで全測 定片の切り出し迄相当の長時日を 要し，罐䏤その後の慗作工程に支㙔 を来たすので先ず全グージ合む約 $200 \times 300 \mathrm{~mm}$ の随园をドリル案孔。 によって测定阰を胴体から切り雖し た.との測定群試験片は更に機械鋯 により各ゲージ每に Fig. 6 の如き 寸法に切断した. No. 1一No. 5 の Block は長さを㩐さ $(55 \mathrm{~mm})$ 01.5倍 にした・これらの作洋の前後におい て試験片から殿除される応力はその 都度測定された。

さて規定の寸法に切断した Block
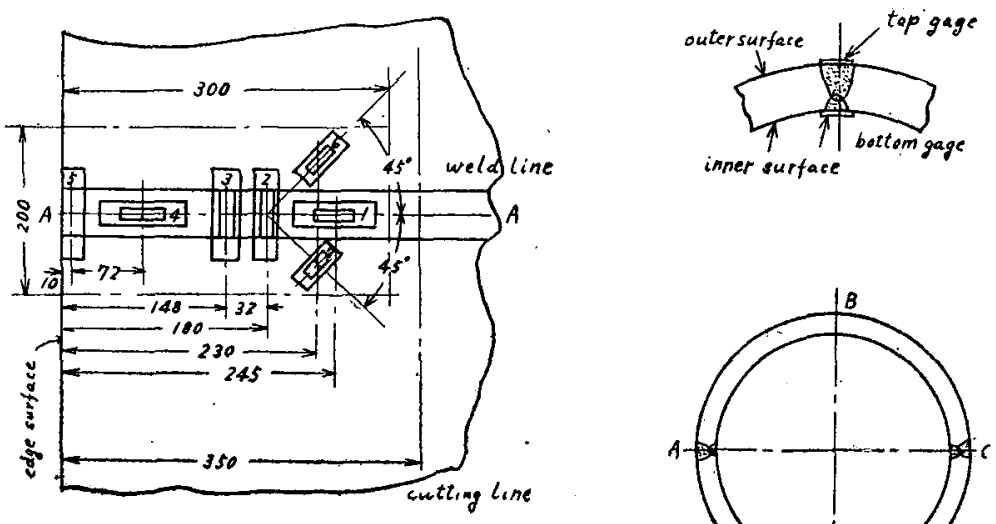
は更に中央部て二つの Block に切断し，そ の各々の半 Block を切断面から外面们。 $\tau 2 \sim 3 \mathrm{~mm}$ 宛平削盤で切削した．この場合 機械加工による試験片の㵋度上昇は測定侮に 譟差を生ずるので，できるだけ切削は light cutting Kし，また解除応广の測定は機械切削 の翌日兑放置して行った。

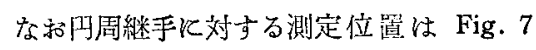
の如くで全円周签接線で 4 ケ所の位置の Longi. 方向 (阴周方向) 括よび Trans. 方向 (軸方向) の応力を先ず分割法によって耐側 洪测定した. 次に板厚方向の念打分布を測定

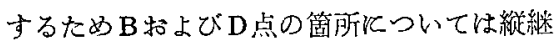
手の場合と同様飞 Longitndinal Block 格よ び Transverse Block t切り出し更に逐次切 削して解除心览存測定した。

\section{5 測 定 結 果}

前述した要領により各 Blockから解除され 万歪の測定結果をTable 3 特よびTable 4 K示 した. 測定部を胢体から切り離す場合には先

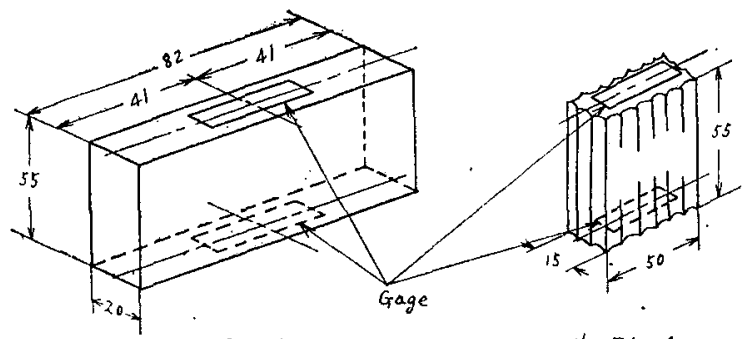

(a) Block for No.1 5 gage

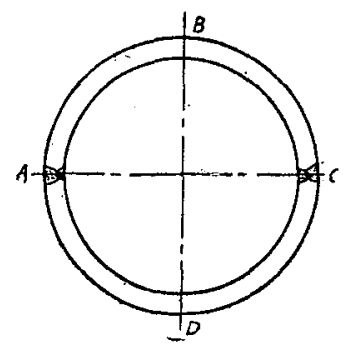

Fig. $=5$ Gage arrangements (longi, seams)

Fig. 6 Dimension of blocks

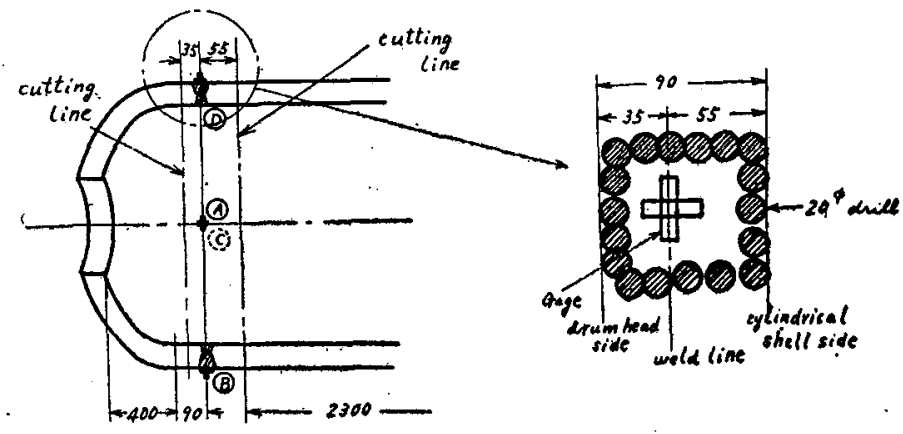

Fig. 7 Gage arrangement (circumfe, seam)

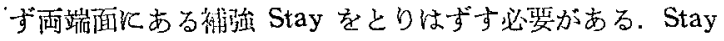
除去汇よって解除される心打予め貼付けた歪計ゲージ より測定しこれを Block切り出し封の解除歪に加頶した.

逐次切削時に和ける解除昰と切削肉厚との関係はFig. 8 の邚くなる、これらの曲線より（7）式の $\frac{d e^{\prime \prime}}{d a}$ 扣よび $\int_{0.5}^{\alpha} \frac{e^{\prime \prime}-e^{\mu 0}}{(1-\mu)^{2}} d \mu$ を図式に計算した。

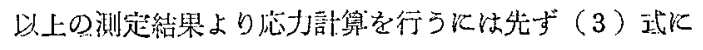
より Block に切り出した場合の平均解除応力在Table 50

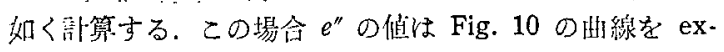

traporation して求めた倌を採用した. Table 5 で計算され た応力は Block を雉胴から切り離した場合に試験片の両 面から解除される平均惢力で Block の内部で惊これらの 両面での忘力が直線的に弛紱されるものと見做される.

Block を切断または切削することによって解除される忘 外 (7)式により詶算される. 計算絬果を Table 6 に示し た. 但し $S^{\prime *}$ は試駼片の長さが厚さの 2 倍以下の場合に 対する禣正を行った值である. $S^{\prime *}$ は Block に残留する 応力值でこれk Block そ切離すことによって解除きれた

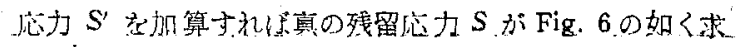
まる。 
Table 3 Relaxed Strain $e^{\prime}$ by Cutting Off the Block $\times 10^{-6}$

(a) Longitudinal weld line

\begin{tabular}{|c|c|c|c|c|c|c|c|c|c|}
\hline \multirow{2}{*}{ Position } & \multirow{2}{*}{ Gage No. } & \multicolumn{4}{|c|}{ As weld } & \multicolumn{4}{|c|}{ Annealed } \\
\hline & & $\begin{array}{c}\text { Stay } \\
\text { removed }\end{array}$ & $\begin{array}{c}\text { Cut off } \\
\text { as a blck }\end{array}$ & $\begin{array}{l}\text { Blocks } \\
\text { cut off }\end{array}$ & Total & $\begin{array}{c}\text { Stay } \\
\text { removed }\end{array}$ & $\begin{array}{c}\text { Cut off } \\
\text { as a blck }\end{array}$ & $\begin{array}{l}\text { Blocks } \\
\text { cut off }\end{array}$ & Total \\
\hline \multirow{7}{*}{ A } & No. $1 \underset{B}{T}$ & $\begin{array}{r}130 \\
55\end{array}$ & $\begin{array}{r}715 \\
1115\end{array}$ & $\begin{array}{l}180 \\
375\end{array}$ & $\begin{array}{l}1025 \\
1545\end{array}$ & $\begin{array}{l}15 \\
30\end{array}$ & $\begin{array}{l}130 \\
125\end{array}$ & $\begin{array}{r}115 \\
-80\end{array}$ & $\begin{array}{r}260 \\
75\end{array}$ \\
\hline & No. $2 \underset{B}{T}$ & $\begin{array}{r}-205 \\
375\end{array}$ & $\begin{array}{r}180 \\
-765\end{array}$ & $\begin{array}{l}110 \\
100\end{array}$ & $\begin{array}{r}85 \\
-290\end{array}$ & $\begin{array}{r}-85 \\
65\end{array}$ & $\begin{array}{r}-60 \\
-180\end{array}$ & $\begin{array}{r}10 \\
0\end{array}$ & $\begin{array}{l}-135 \\
-115\end{array}$ \\
\hline & No. $3 \cdot \frac{T}{B}$ & $\begin{array}{r}-330 \\
445\end{array}$ & $\begin{array}{r}215 \\
-840\end{array}$ & $\begin{array}{r}0 \\
20\end{array}$ & $\begin{array}{l}-115 \\
-375\end{array}$ & $\begin{array}{r}120 \\
70\end{array}$ & -80 & 130 & $\begin{array}{r}-70 \\
-100\end{array}$ \\
\hline & No. $4 \underset{\mathrm{B}}{\mathrm{T}}$ & $\begin{array}{r}115 \\
30\end{array}$ & $\begin{array}{l}325 \\
305\end{array}$ & $\begin{array}{l}370 \\
500\end{array}$ & $\begin{array}{l}810 \\
835\end{array}$ & $\begin{array}{r}-55 \\
5\end{array}$ & $\begin{array}{l}70 \\
15\end{array}$ & $\begin{array}{r}90 \\
-15\end{array}$ & $\begin{array}{r}105 \\
5\end{array}$ \\
\hline & No. $5{ }_{\mathrm{B}}^{\mathrm{T}}$ & $\begin{array}{l}315 \\
-\end{array}$ & $\begin{array}{r}260 \\
-485\end{array}$ & $\begin{array}{r}-415 \\
385\end{array}$ & $\begin{array}{l}-470 \\
-100\end{array}$ & -140 & $\begin{array}{r}-80 \\
-310\end{array}$ & $\begin{array}{r}25 \\
-165\end{array}$ & $\begin{array}{l}-195 \\
-475\end{array}$ \\
\hline & No. $6 \frac{T}{B}$ & $\begin{array}{r}225 \\
30\end{array}$ & $\begin{array}{r}-50 \\
-285\end{array}$ & $\begin{array}{l}185 \\
315\end{array}$ & $\begin{array}{r}360 \\
60\end{array}$ & $\begin{array}{r}-45 \\
5\end{array}$ & $\begin{array}{l}-90 \\
-20\end{array}$ & 165 & $\begin{array}{l}30 \\
\times\end{array}$ \\
\hline & No. $7 \underset{\mathrm{B}}{\mathrm{T}}$ & $\begin{array}{r}-60 \\
205\end{array}$ & $\begin{array}{l}625 \\
245\end{array}$ & - & $\stackrel{x}{x}$ & $\overline{45}$ & $\overline{55}$ & $\overline{75}$ & $\begin{array}{r}\times \\
175\end{array}$ \\
\hline \multirow{7}{*}{ C } & No. $1 \frac{\mathrm{T}}{\mathrm{B}}$ & & $\begin{array}{r}1050 \\
600\end{array}$ & $\begin{array}{l}185 \\
810\end{array}$ & $\begin{array}{l}1365 \\
1465\end{array}$ & & & & $x$ \\
\hline & No. $2 \underset{B}{\mathrm{~T}}$ & & $\begin{array}{r}305 \\
-675\end{array}$ & $\begin{array}{r}65 \\
470\end{array}$ & $\begin{array}{l}115 \\
170\end{array}$ & -110 & 50 & -25 & -85 \\
\hline & No. $3 \underset{B}{T}$ & & $\begin{array}{r}365 \\
-750\end{array}$ & $\begin{array}{r}40 \\
455\end{array}$ & $\begin{array}{r}75 \\
150\end{array}$ & & & & $x$ \\
\hline & No. $4 \underset{\mathrm{B}}{\mathrm{T}}$ & & 665 & $\stackrel{540}{-}$ & $\begin{array}{r}1320 \\
\times\end{array}$ & 45 & 5 & 90 & $140^{\circ}$ \\
\hline & No. $5 \frac{\mathrm{T}}{\mathrm{B}}$ & & 585 & - & $\begin{array}{l}x \\
x\end{array}$ & & & & $x$ \\
\hline & No. $6 \underset{\mathrm{B}}{\mathrm{T}}$ & 4 & $\begin{array}{r}195 \\
-355\end{array}$ & $\begin{array}{l}450 \\
255\end{array}$ & $\begin{array}{r}870 \\
-70\end{array}$ & & & & $x$ \\
\hline & No. $7 \underset{\mathrm{B}}{\mathrm{T}}$ & & $\begin{array}{r}700 \\
70\end{array}$ & $\begin{array}{r}-455 \\
145\end{array}$ & $\begin{array}{l}185 \\
420\end{array}$ & -25 & 135 & -10 & 100 \\
\hline \multirow{3}{*}{ B } & No. $1 \underset{\mathrm{B}}{\mathrm{T}}$ & $\begin{array}{l}20 \\
50\end{array}$ & $\begin{array}{r}230 \\
-340\end{array}$ & $\begin{array}{r}-60 \\
-205\end{array}$ & $\begin{array}{r}190 \\
-495\end{array}$ & $\begin{array}{l}10 \\
15\end{array}$ & $\begin{array}{r}75 \\
-125\end{array}$ & -5 & $\begin{array}{l}80 \\
\times\end{array}$ \\
\hline & No. $2 \underset{B}{\mathrm{~T}}$ & $\begin{array}{l}20 \\
40\end{array}$ & $\begin{array}{r}-310 \\
110\end{array}$ & $\begin{array}{r}270 \\
-265\end{array}$ & $\begin{array}{r}-20 \\
-115\end{array}$ & $\begin{array}{r}-20 \\
0\end{array}$ & $\overline{85}$ & $-\overline{25}$ & $\begin{array}{r}x \\
60\end{array}$ \\
\hline & No. $6 \frac{T}{B}$. & $\begin{array}{l}10 \\
50\end{array}$ & $\begin{array}{r}-55 \\
-130 \\
\end{array}$ & $\begin{array}{r}-105 \\
-105 \\
\end{array}$ & $\begin{array}{l}-150 \\
-185 \\
\end{array}$ & $\begin{array}{r}0 \\
-15 \\
\end{array}$ & $\begin{array}{r}-20 \\
-55 \\
\end{array}$ & $-1 \overline{0}$ & $\begin{array}{c}\times \\
30 \\
\end{array}$ \\
\hline \multirow{3}{*}{ D } & No. $1 \frac{T}{B}$ & & $\begin{array}{r}210 \\
-365\end{array}$ & -60 & $\begin{array}{c}150 \\
\times\end{array}$ & $\begin{array}{r}-20 \\
45\end{array}$ & $\begin{array}{r}70 \\
-95\end{array}$ & -100 & $\begin{array}{r}-50 \\
\times\end{array}$ \\
\hline & No. $2 \underset{\mathrm{B}}{\mathrm{T}}$ & & $\begin{array}{r}-465 \\
200\end{array}$ & -60 & $\begin{array}{r}-505 \\
\times\end{array}$ & $\begin{array}{r}80 \\
-30\end{array}$ & $\begin{array}{r}-185 \\
15\end{array}$ & $\begin{array}{l}-55 \\
-30\end{array}$ & $\begin{array}{l}-160 \\
-45\end{array}$ \\
\hline & No. $6 \frac{\mathrm{T}}{\mathrm{B}}$ & & $\begin{array}{r}-135 \\
40\end{array}$ & $\begin{array}{r}-385 \\
225\end{array}$ & $\begin{array}{r}-500 \\
315\end{array}$ & $\begin{array}{r}-20 \\
40\end{array}$ & $\begin{array}{l}-30 \\
-60\end{array}$ & $-\overline{25}$ & $\begin{array}{r}x \\
-45\end{array}$ \\
\hline
\end{tabular}

(b) Circumferential weld line (As weld)

\begin{tabular}{|c|c|c|c|c|c|c|c|c|}
\hline \multirow[b]{2}{*}{ Direction } & \multicolumn{4}{|c|}{$\mathrm{C}_{1}$ Weld line } & \multicolumn{4}{|c|}{$\mathrm{C}_{2}$ Weld line } \\
\hline & $\mathrm{A}$ & B & $\mathrm{C}$ & $\mathrm{D}$ & $\mathrm{A}$ & $\mathrm{B}$ & $\mathrm{C}$ & $\mathrm{D}$ \\
\hline Longi. strain $\underset{B}{T}$ & 1100 & $\begin{array}{l}1100 \\
1050\end{array}$ & 1125 & $\begin{array}{r}1150 \\
775\end{array}$ & $\begin{array}{r}825 \\
1050\end{array}$ & $=$ & $\begin{array}{l}1200 \\
1075\end{array}$ & $\begin{array}{l}250 \\
775\end{array}$ \\
\hline Trans, strain ${ }_{B}^{T}$ & - & $\begin{array}{r}-140 \\
500\end{array}$ & $\begin{array}{r}-150 \\
430\end{array}$ & $\begin{array}{r}-265 \\
500\end{array}$ & $\begin{array}{r}-45 \\
400\end{array}$ & - & $\begin{array}{r}-280 \\
410\end{array}$ & $\begin{array}{r}-115 \\
625\end{array}$ \\
\hline
\end{tabular}



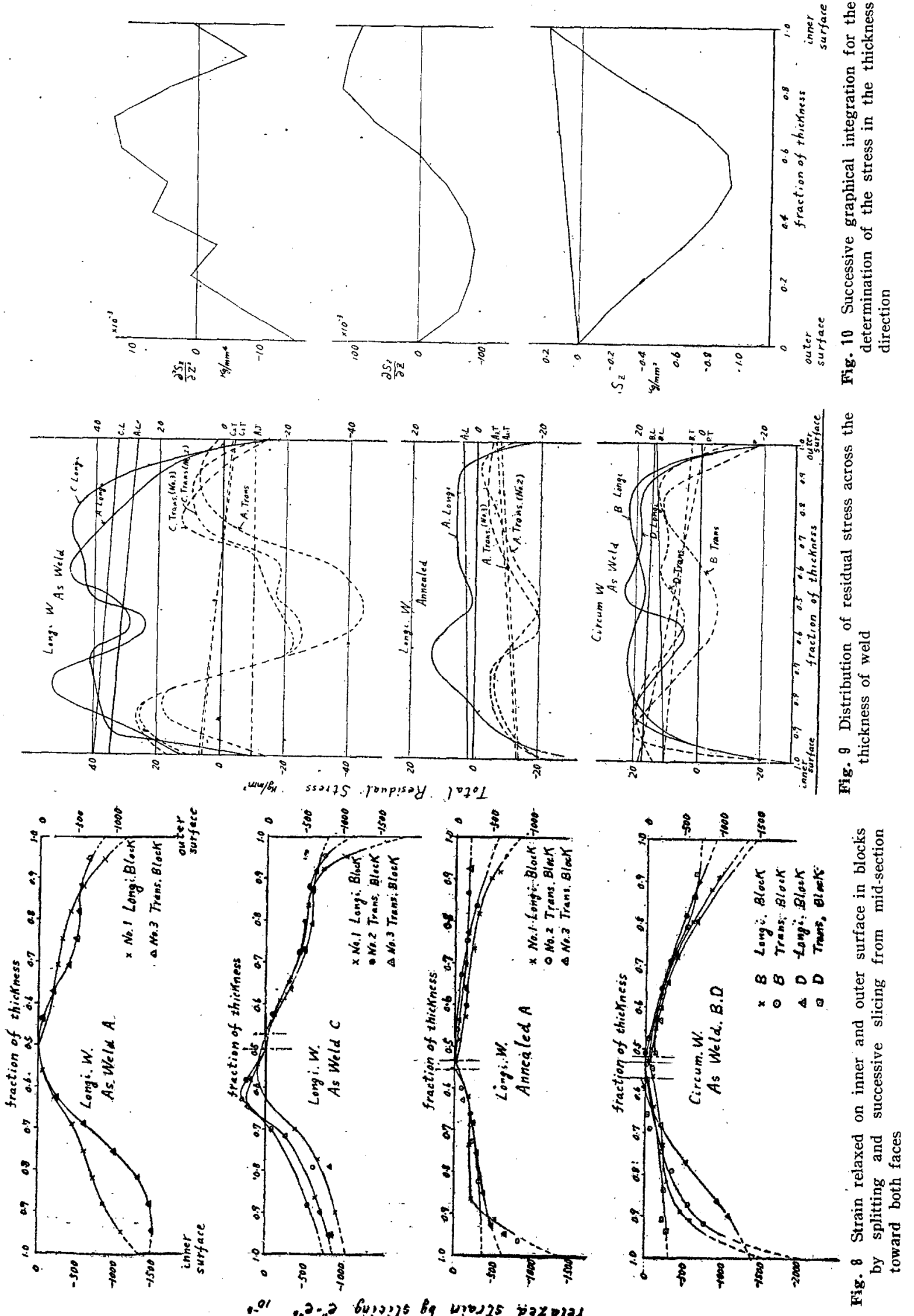
Table 4 Relaxed Strain by Sptitting the Block in Half

\begin{tabular}{|c|c|c|c|c|c|c|c|c|}
\hline \multicolumn{4}{|c|}{ Longi. weld } & \multicolumn{5}{|c|}{ Circum. weld $\left(\mathrm{C}_{1}\right)$} \\
\hline \multirow{2}{*}{ Block } & \multicolumn{2}{|c|}{ As weld } & \multirow{2}{*}{$\frac{A n n}{A}$} & \multirow{2}{*}{ Block } & \multicolumn{2}{|c|}{$\mathrm{B}$} & \multicolumn{2}{|c|}{$\mathrm{D}$} \\
\hline & A & C & & & $e^{\prime}$ & $e^{n} 0$ & $e^{\prime}$ & $e^{\prime \prime 0}$ \\
\hline No. $1 \frac{T}{B}$ & $\begin{array}{l}-785 \\
-440\end{array}$ & $\begin{array}{r}-465 \\
-10\end{array}$ & $\begin{array}{r}-50 \\
-410\end{array}$ & Longi. ${ }_{\mathrm{B}}^{\mathrm{T}}$ & $\begin{array}{l}1100 \\
1050\end{array}$ & $\begin{array}{l}-185 \\
-245\end{array}$ & $\begin{array}{r}1150 \\
775\end{array}$ & $\begin{array}{l}-285 \\
-245\end{array}$ \\
\hline No. $2 \underset{\mathrm{B}}{\mathrm{T}}$ & & $\begin{array}{r}725 \\
1170\end{array}$ & $\begin{array}{r}225 \\
75\end{array}$ & Trans. $\frac{T}{B}$ & $\begin{array}{r}-140 \\
500\end{array}$ & $\begin{array}{l}350 \\
440\end{array}$ & $\begin{array}{r}-265 \\
500\end{array}$ & $\begin{array}{r}-35 \\
105\end{array}$ \\
\hline No. $3 \stackrel{\mathrm{T}}{\mathrm{T}}$ & $\begin{array}{l}1290 \\
1280\end{array}$ & $\begin{array}{r}345 \\
1050\end{array}$ & $\begin{array}{l}170 \\
265\end{array}$ & & & & & \\
\hline
\end{tabular}

Table 5 Relaxed Stress by Cutting Off the Block

\begin{tabular}{|c|c|c|c|c|c|c|c|c|c|c|c|c|}
\hline \multirow{4}{*}{ Seam } & \multicolumn{8}{|c|}{ Longi. weld } & \multirow{2}{*}{\multicolumn{4}{|c|}{$\begin{array}{l}\text { Circum. weld } \\
\text { As weld }\end{array}$}} \\
\hline & \multicolumn{5}{|c|}{ As weld } & \multirow{2}{*}{\multicolumn{3}{|c|}{$\frac{\text { Annealed }}{\mathrm{A}}$}} & & & & \\
\hline & \multicolumn{2}{|c|}{ A } & \multicolumn{3}{|c|}{$\mathrm{C}$} & & & & \multicolumn{2}{|c|}{$\mathbf{B}$} & \multicolumn{2}{|c|}{ D } \\
\hline & No. 1 & No. 3 & No. 1 & No. 2 & No. 3 & No. 1 & No. 2 & No. 3 & $\mathbf{L}$ & $T$ & $\mathrm{~L}$ & $T$ \\
\hline$e_{t}^{\prime}$ & 1025 & -115 & 1365 & 115 & 75 & 260 & -135 & -70 & 1100 & -140 & 1150 & -265 \\
\hline$e_{b}^{\prime}$ & 1545 & -375 & 1465 & 170 & 150 & 75 & -115 & -110 & 1050 & 500 & 775 & 500 \\
\hline$e^{\prime \prime} t$ & -1935 & 445 & -2250 & -400 & -450 & -900 & -325 & -30 & -1500 & -550 & -1700 & -750 \\
\hline$e^{\prime \prime}{ }_{b}$ & -1800 & -220 & -1100 & 400 & 150 & -1800 & -310 & -380 & -1850 & -1650 & -1650 & -200 \\
\hline$S_{t}^{\prime}$ & 27.0 & -9.7 & 33.2 & -2.8 & -3.6 & 4.3 & -3.0 & -6.0 & 15.0 & 3.0 & i 4.2 & -0.5 \\
\hline$S_{b}^{\prime}$ & 34.5 & -10.1 & 39.7 & 5.9 & 6.3 & 1.7 & -14.1 & -13.6 & 17.6 & 10.4 & 10.3 & 18.3 \\
\hline
\end{tabular}

Table 6-I Computation of Residuel Stress by Splitting and Slicing (Longitudinal Weld Line A)

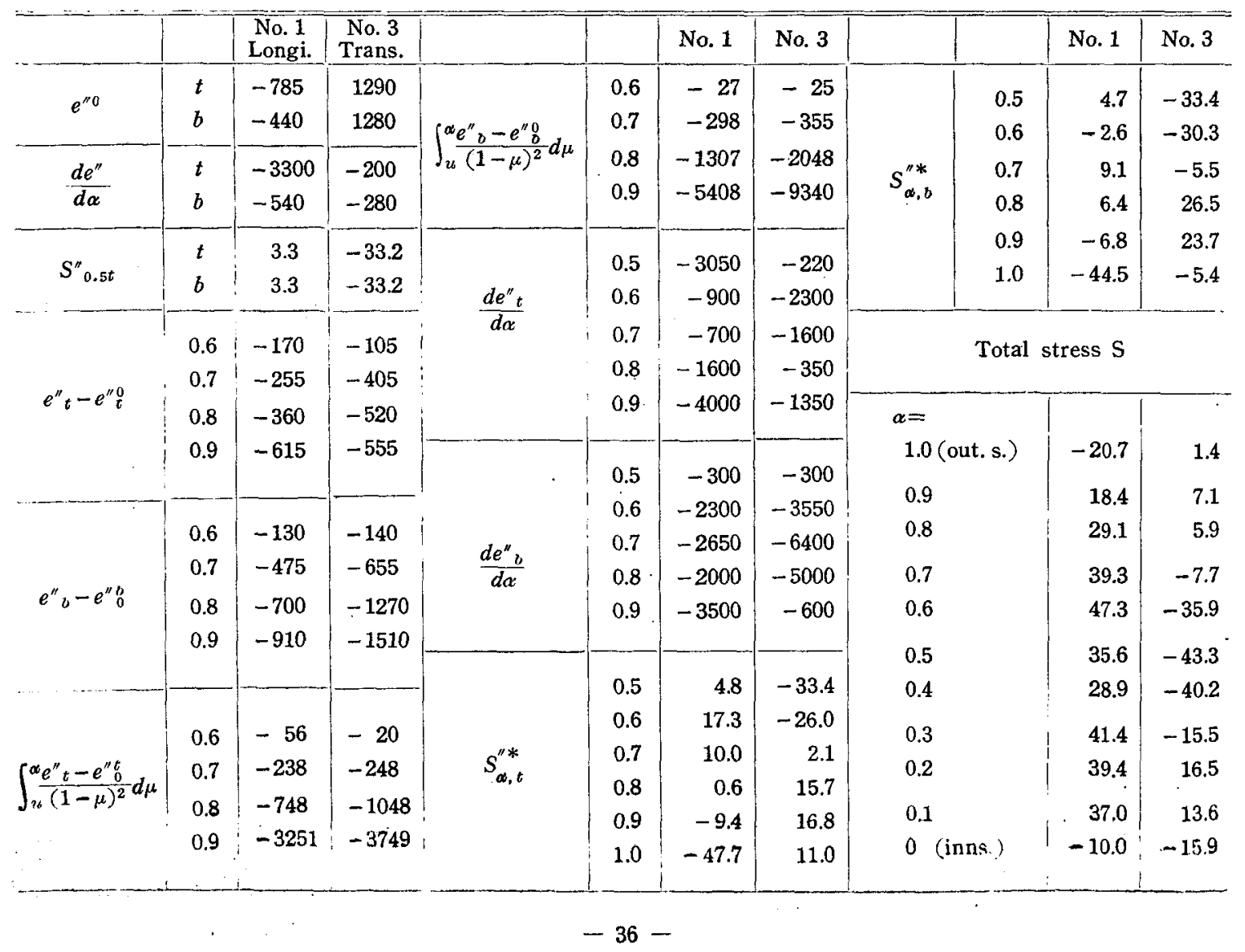


Table 6-II Total Stress S

\begin{tabular}{|c|c|c|c|c|c|c|c|c|c|c|}
\hline & \multicolumn{6}{|c|}{ Longitudinal weld } & \multirow{2}{*}{\multicolumn{4}{|c|}{ Circumferential weld }} \\
\hline & \multicolumn{3}{|c|}{ As weld C } & \multicolumn{3}{|c|}{ Annealed A } & & & & \\
\hline & No. 1 & No. 2 & 3 & No. 1 & & & \multicolumn{2}{|c|}{ B } & \multicolumn{2}{|c|}{$\mathrm{D}$} \\
\hline & L & $T$ & $T$ & $\mathrm{~L}$ & 1 & $f$ & $\mathbf{L}$ & $\mathrm{T}$ & $\mathbf{L}$ & $T$ \\
\hline 1.0 & -22.3 & -12.7 & -14.6 & -17.9 & $\mid-15.0$ & -6.7 & -22.0 & -10.5 & -27.8 & -19.5 \\
\hline 0.9 & 26.5 & 7.3 & 1.6 & 4.2 & -2.9 & -4.5 & 16.3 & 10.7 & 12.8 & 1.8 \\
\hline 0.8 & 44.0 & 9.4 & 10.1 & 5.6 & -6.4 & -5.2 & & 11.7 & 18.2 & 10.8 \\
\hline 0. & 47.6 & 3.2 & 8.9 & 5.1 & -9.9 & -6.9 & 20.2 & 5.2 & 17.6 & 9.1 \\
\hline 0.6 & 43.5 & -17.4 & $\mid-11.9$ & 4.0 & -14.9 & -11.4 & 17.5 & -2.2 & 20.2 & 11.5 \\
\hline 0.5 & 41.5 & -17.0 & -14.3 & 0.1 & -20.6 & -17.7 & 16.3 & -6 & 21.3 & 5.9 \\
\hline 0.4 & 23.6 & -25.0 & -21.3 & 8.9 & -15.9 & -20.1 & 20.6 & -3 & 3.9 & 5.3 \\
\hline 0.3 & 41.0 & -16.2 & -17.3 & 12.1 & -8.1 & -6.9 & 21.8 & 2.7 & 10.5 & 13.2 \\
\hline 0. & 52.4 & 16.4 & 17.7 & 3.3 & -7.1 & -6.6 & 15 & 12.2 & 18.1 & 18.2 \\
\hline 0. & 33.1 & 28.0 & 24.6 & -5.9 & -11.0 & -9.3 & 10.7 & 19.3 & 14.0 & 18.2 \\
\hline 0 & 12.6 & 15.8 & 9.3 & -42.8 & $\mid-21.8$ & -23.0 & -28.0 & -30.3 & -30.7 & 13.3 \\
\hline
\end{tabular}

Block を二つに分梙する場合実際には上下に二等分され ない場合がある．この場合には板厚を 1 として切断面を下 而より は次の如く表わされる.

$$
\begin{aligned}
& S_{\alpha}{ }^{\prime \prime}=E\left[\frac{1}{2} \frac{d e_{t}{ }^{\prime \prime}}{d \alpha}(1-\alpha)-2\left(e_{t}^{\prime \prime}-e^{\prime \prime}{ }_{t}\right)+3(1-\alpha)\right. \\
& \left.\int_{u c}^{\infty} \frac{e_{t}^{\prime \prime}-e^{\prime \prime}}{(1-\mu)^{2}} d \mu+\frac{(3-u) \alpha-2}{1-\mu} e^{\prime \prime}{ }_{t}^{0}+\frac{u^{2}}{(1-u)^{2}}(1-\alpha) e^{\prime \prime} \begin{array}{c}
0 \\
b
\end{array}\right]
\end{aligned}
$$

Table 7 Computation of Shearing Stress and Stress in the Direction of Thickness

\begin{tabular}{|c|c|c|c|c|c|c|c|}
\hline \multirow{2}{*}{$\begin{array}{l}\text { Thick } \\
\text { ness }\end{array}$} & \multicolumn{2}{|c|}{ Trans. stress } & \multirow{2}{*}{\begin{tabular}{|c}
$\frac{2}{\left(\Delta y_{1}\right)^{2}}$ \\
$\times\left(S_{3}-S_{2}\right.$ \\
$10^{-3}$
\end{tabular}} & \multirow{2}{*}{$\begin{array}{r}\frac{2}{\Delta y_{2} \Delta x_{2}} T \\
10^{-3}\end{array}$} & \multirow{2}{*}{$\mid \begin{array}{c}\frac{\partial^{2} S_{z}}{\partial Z^{2}} \\
10^{-3}\end{array}$} & \multirow{2}{*}{$\frac{\partial S z}{\partial Z}$} & \multirow{2}{*}{$\begin{array}{c}S_{Z} \\
\mathrm{~kg} / \mathrm{mm}^{2}\end{array}$} \\
\hline & $S_{2}$ & $S_{3}$ & & & & & \\
\hline 0 & 15.8 & 9.3 & -12.7 & -3.1 & -15.8 & 0 & 0 \\
\hline 0.1 & 7.0 & 24.6 & -4.7 & -2.4 & -7.1 & -63 & -0.19 \\
\hline 0.2 & 16.4 & 17.7 & 2.5 & -1.6 & 0.9 & -80 & -0.43 \\
\hline 0.3 & -16.2 & -17.3 & -2.1 & -0.9 & -3.0 & -85.8 & -0.68 \\
\hline 0.4 & -25.0 & -21.3 & 7.2 & -0.1 & 7.1 & -74.5 & -0 \\
\hline 0.5 & -17.0 & -14.9 & 4.1 & 0.7 & 4.8 & -41.8 & -1.04 \\
\hline 0.6 & -17.4 & -11.9 & 10.7 & 1.4 & 12.1 & 4.7 & -1.04 \\
\hline 0.7 & -3.2 & 8.9 & 11.1 & 2.2 & 13.3 & 74.5 & -0 \\
\hline 0.8 & 9. & 10.1 & 1.4 & 2. & 4.3 & 122.9 & -0.54 \\
\hline 0.9 & 7.3 & 1.6 & -11.1 & 3.7 & -7.4 & 114.4 & -0.24 \\
\hline 1.0 & -12.7 & -14.6 & -3.7 & 4.4 & 0.7 & 96.6 & 0 \\
\hline
\end{tabular}

\begin{tabular}{c|c|c|c|c|c}
\hline Face & Block & Axis & $e^{\prime}$ & $e^{\prime}{ }^{\prime}-e^{\prime} v$ & $\mathrm{~T}$ \\
\hline \multirow{2}{*}{ Top } & C-No. 6 & $\mathrm{V}$ & 870 & 685 & 5.5 \\
& C-No. 7 & $\mathrm{W}$ & 185 & & \\
Botton & C-No. 6 & $\mathrm{V}$ & -70 & -490 & 3.9 \\
\hline
\end{tabular}

次炕厚味方向の応力を求める。この場 合 (9) 式は签接線の中央部に招いて成 立し，本例の如き場合には適用するとと は不適当と思われるが一応との部分にる Longi. Stressは聺接線方向变化しない と見做して $S_{Z}$ を計算した．繸継手飞対 する計算結果を Table 7 K示した.

厚味方向心力の分布を Fig. 10 亿示し た. 図に示される如く板愿方向の态力は 板厚中央で最大となるがその佔は約 1 $\mathrm{kg} / \mathrm{mm}^{2}$ 程度で極めて小さい，彷って 本供試体の如き厚板の場合でも板厚方向 とは大きな残留忘力は存在せず注が二軸 性の心力分布と見てょい。

\section{9 結 言}

上述した如くユニオンメルト自動熔接䍊胴の三柚方向残

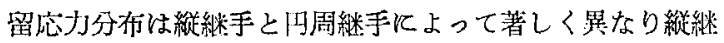
手では熔接部の内部汇ほが熔着金の降伏点附近の引張応力 結が熔接線方向に存在する.（熔着金の降伏点䒠測の結 果 $47 \sim 50 \mathrm{~kg} / \mathrm{mm}^{2}$ の傎を示した）また周方向の心力 (Trans. Stress) の中央部で最大となり，その值は $40 \mathrm{~kg} /$ $\mathrm{mm}^{2}$ 以上の压縮成力となる. 円周継手の Longi. Stress は 板の表面附近では両面共圧縮力であるが內部に入るに彷っ 急激化引張応力となる。しかし応力值は. $20 \mathrm{~kg} / \mathrm{cm}^{2}$ 程度 で縦継手飞比較して遥か飞少ない. Trans. Stress 屯汪上 んど同様の分布傾问を有するが板厚㠹决部の忘力值は小さ

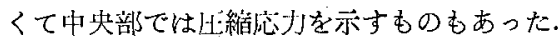

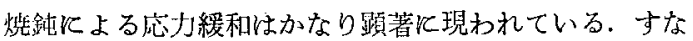
わち縦継手では倠部の応力は Longi. 方向で $10 \mathrm{~kg} / \mathrm{mm}_{2}$ 附近飞，また Trans. 方向です $20 \mathrm{~kg} / \mathrm{mm}^{2}$ 以下飞緩和さ

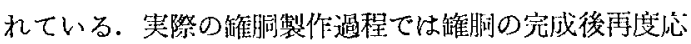
力除去烧鈍が行われるので，実際の熔接残留応力はこれ より更に楥和されているものと見てょい．

\section{交献}

1) D. Rosenthal \& J. T. Norton, "A Method of Measuring Triaxial Residual Stresses." Weld. Jl., May 1945, 295s 307s

2) E. Paul De Garmo, J. L. Meriam \& F. Jonassen, "The Effect of Weld Length upon the Residual Stresses of Unrestrained Butt Welds." Weld. Jl., Aug. 1946, 486s $487 \mathrm{~s}$ 